\title{
PROFESSIONAL BACKGROUNDS OF ACADEMICS IN THE CIVIL AVIATION DEPARTMENTS IN TURKEY
}

\section{DOI: 10.17261/Pressacademia.2021.1468 \\ RJBM- V.8-ISS.4-2021(5)-p.271-278}

Serdar Kizilcan'1, Kagan Cenk Mizrak ${ }^{2}$

${ }^{1}$ Usak University, Civil Aviation Vocational School, Usak, Turkey. serdarkizilcan@usak.edu.tr, ORCID: 0000-0002-8209-2804

2Usak University, Civil Aviation Vocational School, Usak, Turkey.

kagan.mizrak@usak.edu.tr, ORCID: 0000-0003-4447-2141

\begin{tabular}{l}
\hline Date Received: October 3, $2021 \quad$ Date Accepted: December 9, $2021 \quad$ open OPAccEss $\quad$ (cc) BY \\
\hline To cite this document \\
Kizilcan, S., Mizrak, K. C., (2021). Professional backgrounds of academics in the Civil Aviation Departments in Turkey. Research Journal of \\
Business and Management (RJBM), 8(4), 271-278. \\
Permanent link to this document: http://doi.org/10.17261/Pressacademia.2021.1468 \\
Copyright: Published by PressAcademia and limited licensed re-use rights only.
\end{tabular}

\section{ABSTRACT}

Purpose- The aim of this study is to examine the professional backgrounds of the lecturers working in the civil aviation cabin services program and compare them in terms of private and state universities. Instructors play an important role in the training and development of the qualified workforce needed by the aviation industry. At the same time, this study aims to contribute to the literature and to offer suggestions about what can be done in the programs that provide education in the field of aviation.

Methodology- In this study, the list of private and state universities that accept students to the civil aviation cabin services program was created by examining the 2021 Higher Education Programs and Quotas Guide of OSYM. According to the list created, the web pages of the relevant vocational schools were scanned and the cv's and contact addresses of the instructors were reached. Information forms prepared within the scope of the relevant study were sent to the e-mail addresses of the instructors who did not have a CV on the website.

Findings- In the findings obtained as a result of the research, the number, graduation and sector experiences of the academicians working in the civil aviation cabin services program in private and public universities are given.

Conclusion- Considering the findings of the study; There are a total of 41 civil aviation cabin services programs, 24 of which are in private and 17 in state universities, that accept students according to the 2021 guideline of OSYM. Considering the programs currently waiting to be approved by YÖK, it is seen that this program has increased rapidly in recent years.

Keywords: Civil aviation, cabin crew, cabin attendant, academic staff JEL Codes: 123, L93, M53

\section{INTRODUCTION}

Civil aviation is one of the fastest growing sectors in the global economy and in our country. With the increase in the number of passengers carried by airline companies in the world, many airline companies have been involved in the sector and the airline companies operating have increased the number of flight points. The number of passengers in our country, which was less than 1 million in the 1960s, exceeded 10 million in 1988, 50 million in 2005, and 100 million in 2010. In 2018, more than 210 million passengers were served at Turkish airports. The COVID-19 epidemic, which affected the whole world in 2020, seriously affected the aviation industry in our country (DHMi, 2020).

In general, the growth of the airline industry and the increase in companies brought the need for cabin crew. One of the factors in the sustainable growth of the civil aviation industry from past to present is meeting the need for qualified personnel. At the same time, the increasing competitive conditions as a result of the sectoral growth in our country force airline companies operating both on domestic and international routes to provide better quality service and to meet the expectations of their customers. Providing quality service and meeting expectations is possible with the presence of qualified and sectorally trained staff.

Therefore, the civil aviation cabin services program has started to take its place in universities in order to reduce the workload of training given in airline companies and to train qualified personnel. The main purpose of the cabin services program is to train cabin crew candidates who know the duties and responsibilities of cabin crew, what to do in emergency situations, 
teamwork, passenger relations and have a good command of many other issues. For this reason, there is always a need for lecturers who can be role-models for students, make them love aviation and convey their professional experience.

This study, unlike other studies in the field of aviation, dealt with the lecturers working in the civil aviation cabin services program. In the study, first of all, the history of civil aviation activities and cabin crew in Turkey is given, then the duties and responsibilities of cabin crew, personality traits, attitudes and behaviors are mentioned. Then, general information about vocational schools and civil aviation cabin services programs in Turkey was given and finally, suggestions were made according to the findings of the study.

\section{LITERATURE REVIEW}

\subsection{History of Civil Aviation Activities in Turkey}

The first civil aviation activities in Turkey started in 1912 in a small area with two hangars around Atatürk Airport. The institutional foundations of Turkish Civil Aviation were laid with the Turkish Aircraft Society, which was founded in 1925 and later renamed the Turkish Aeronautical Association. The first civil air transport was started in 1933 with a small fleet of 5 planes under the name of "Turkish Air Mail". Established under the Ministry of National Defense, the "Airline State Operations Administration" has been assigned to carry out civil air transportation (Shgm Tarihçe, 2021).

In 1936, the foundations of the Sky School were laid by Nuri Demirağ, one of the businessmen of the period, in the Divriği district of Sivas. In addition to the study workshop in Beşiktaş, the first civil airport was established in Yeşilköy with the name "Sky Stadium". By establishing hangars, workshops and the Sky School right next to the airport, aircraft production and aviation training began. In 1939, with the encouragement of Nuri Demirağ, an airplane branch was established within the Mechanical Branch of the High Engineering School to train aircraft engineers. The first Turkish type passenger plane, Nu D.38, whose model was drawn by Turkish engineers and whose all parts, except the engine, were unearthed by the efforts of Turkish workers, was manufactured. Nu D.38 aircraft continued its flights between Ankara and Istanbul for a while, and Bursa, İzmir; After Athens and Thessaloniki, expeditions were organized to Sakarya, Eskişehir, Kayseri and Sivas (Dervişoğlu, 2017).

In addition to being a party to the Chicago Convention in 1945, Turkey also became one of the founding members of the International Civil Aviation Organization (ICAO), which forms the basis of civil aviation. With the advancement of technology and the rapid development of the civil aviation industry in the world, the "Civil Aviation Department" was established under the Ministry of Transport in 1954 in order to protect the interests of the country and to ensure the regular conduct of international relations. This institution was later reorganized as the "General Directorate of Civil Aviation" (Shgm Tarihçe, 2021).

The first international voyage was made in 1947 from Istanbul to Athens. In 1951, flights were organized to new destinations such as Nicosia, Beirut and Cairo. In 1983, 2.5 million passengers were carried, and after the flights to Europe, the Middle East and the Far East, flights were also organized to America (Türk Hava Yolları, 2021).

Air transport activities continued under the monopoly of Turkish Airlines until the mid-1980s, and the state implemented restrictive policies regarding civil aviation activities. Changes in economic policies in Turkey in 1983 affected the civil aviation industry. The "Civil Aviation Law" numbered 2920 came into effect and the liberalization process in Turkish civil aviation began. This law granted the private sector the right to operate and operate air transport at national and international level for commercial purposes (Battal, Yılmaz and Ateş, 2006).

Therefore, apart from Turkish Airlines, private airline companies also started to operate scheduled domestic flights. In this process, due to the increasing competition conditions, ticket prices started to be sold more affordable and the number of passengers preferring air transportation increased. As a result, the contribution of the aviation industry to the national economy has increased.

\subsection{History of Cabin Crew}

In 1922, Britain's Daimler Airway first laid the foundations of this profession with its personnel called "steward". In 1930, the owner of Boeing Air Tarnport, Steve Stimpson, created the profession he called "cabin attendant" and started the nurse named Ellen Church with the title of first cabin crew. The reason why cabin crew members were chosen among nurses was that passengers who had just started boarding the plane had health problems such as sensitivity to cabin pressure, fear of heights and flying, and risk of encountering them. While the nurses were helping the passengers with their health, they also offered refreshments (Çolak, 2013).

\subsection{Definition of Cabin Crew}

Persons responsible for the implementation of necessary safety and security measures and passenger comfort in aircraft carrying passengers are defined as "cabin attendants" or "cabin crew". Cabin Attendants; It functions in the cabin section of 
the aircraft for safe, secure and comfortable flight. Those who successfully complete their training by meeting the conditions specified in the relevant legislation published by the General Directorate of Civil Aviation are entitled to receive the "Cabin Attendant Certificate" (Shgm Kabin Memuru, 2021).

\subsection{Duties and Responsibilities of Cabin Crew}

Generally, the duties and responsibilities of flight attendants other than catering services are not known. The main duties and responsibilities of flight attendants; we can list such as cleaning the plane, responding in emergency situations, welcoming passengers and counting safety throughout the flight. (if there is no doctor/nurse on board), applying basic first aid, applying the relevant procedure according to the captain's commands in emergencies, reporting the malfunctions detected in the cabin during the flight to the technical department, reporting unsafe or risky situations/events to the company's safety management unit, performing the security control of the aircraft at the end of the flight to be done (Kızılcan ve Demiral, 2021).

\subsection{Personal Characteristics of the Cabin Crew}

Personality is a condition that affects the way people think and behave and can be observed differently in each person. Cabin crew is a profession that requires certain personality traits to come together. Some of the personality traits of the cabin crew come to the forefront, which makes it necessary to be in constant communication with passengers, ground workers, cockpit crew and teammates. Cabin crew; They should have good communication, being in control, being compatible with teamwork, being patient and sensitive (Baltaş, 2009: 23).

\subsection{Attitudes and Behaviors of Cabin Crew}

The attitudes and behaviors that the cabin crew should exhibit are listed as follows:

1- To be kind to teammates and passengers, to be smiling,

2- Creating the impression that it is a pleasure to serve the passenger,

3- To meet the passenger's requests to the extent of the available possibilities, if this is not possible, to explain the situation to the passenger in a rational and polite language,

4- Not to give misleading information about the company and colleagues,

5- Being compatible with colleagues,

6- To represent the company in the best way,

7- Fulfilling company procedures and standards during the task,

8- To stay away from behaviors that will damage the prestige of the company,

9- To obey the uniform rules,

10- To empathize,

11- Being calm in stressful situations (Aktunç, 2013).

\subsection{Overview of Vocational Schools}

The rapid increase in the world population, the increase in competition in business life and technological developments bring along the need for an educated workforce. It is very important to train a qualified workforce and to benefit from this workforce, especially for developing countries. One of the projects implemented to meet this workforce need is the establishment of vocational schools.

The main purpose of the education given in vocational schools is to train qualified intermediate staff especially for the trade and service sector. For this reason, the education given in these schools should be good and of high quality. Increasing competition conditions make companies feel the need to be one step ahead. One of the most important conditions for realizing this is that companies have well-trained and qualified personnel. Undoubtedly, vocational schools have a great role in the training and preparation of these personnel for the sector.

The business world needs human resources with both intellectual and physical competencies. This need is also necessary for the development of countries. In order to meet this need, vocational schools provide education at the higher education level. Among the aims of vocational schools are to provide students with basic skills, to communicate with sector employees, and to provide students with competence in social and moral development (Turan, 2002: 275). 
Apart from raising intermediate manpower, vocational schools also pay attention to the qualifications of individuals such as thinking, researching, questioning, criticizing, keeping up with change, knowing a foreign language, and contributing to social and cultural activities. Considering that it is an important process in both the development of the country's economy and the prevention of unemployment by preparing individuals for working life in a short time, it is seen that vocational education is an important advantage for the country (Günal and Koçak, 2003).

Vocational schools undertake the most important task in terms of providing a profession in the modern education system. Vocational schools continue their work in different ways today. While vocational colleges that try to fulfill different functions operate within the body of state universities and foundation universities, some vocational colleges that have been opened recently also provide education services independently (Bolat, 2011: 34).

\subsection{Program of Civil Aviation Cabin Services}

Civil Aviation Cabin Services program is an associate degree program that trains cabin attendants to work in airline companies. The main purpose of this program is to train a qualified workforce that has strong communication skills and can respond to the problems they encounter with an immediate solution focus. Graduates of this program can be employed in airline companies, in different fields of activity of airports and in enterprises related to the aviation sector (Bingöl Sbmyo, 2021).

The right to operate air transport and airport operations to the private sector was granted with the Turkish Civil Aviation Law No. 2920 published in 1983. As a result of this, a great development has started in Turkish Civil Aviation and the need for qualified personnel has increased rapidly. The first step towards meeting this need was taken soon after and the Civil Aviation Vocational School was established in 1986 with the resources provided by the Turkish Government and the International Civil Aviation Organization (ICAO) (Eskişehir Teknik Üniversitesi, 2021).

The first civil aviation cabin services program was opened in Kapadokya Vocational School. At the same time, this program is authorized to provide Cabin Crew Basic Training in accordance with the Cabin Crew Instruction (SHT-CC) published by the General Directorate of Civil Aviation (Kapadokya, 2021).

In recent years, the number of civil aviation cabin services programs in state and foundation universities has been increasing. Considering the number of quotas in public universities, it is seen that almost all of the program quotas are filled.

In this program, theoretically and practically; Courses such as crew resource management, aviation English, catering and catering are offered (Uşak Shmyo, 2021).

Candidates who want to be cabin crew; Qualities that love to travel, have leadership qualities, are cool-headed, are prone to teamwork and communicate well are sought.

The Program Enrollment Conditions are:

- Not having a criminal record or a criminal record archive record.

- For women, to be between $160 \mathrm{~cm}$ and $180 \mathrm{~cm}$ tall. (to be no more than 5 kilograms more or 15 kilograms less than the last two digits of the value of height expressed in centimeters)

- For men, be between 170 and $190 \mathrm{~cm}$ tall. (weight no more than 5 kilograms more or 15 kilograms less than the last two digits of height expressed in centimeters)

- Health status to be suitable for flight. (They are required to receive a report from health institutions authorized by the General Directorate of Civil Aviation that their health status is suitable for flight)

- Not having tattoos and scars on the visible parts of the body when wearing the cabin crew uniform (Ösym Kılavuz Bilgisi, 2021).

\section{DATA AND METHODOLOGY}

\subsection{Restrictions of the Research}

The curriculum vitae of the lecturers were obtained from the web pages of the universities they are affiliated with. While there was no problem in accessing the curriculum vitae of the lecturers in state universities, it was observed that some of the curriculums of the lecturers in private universities were not included. An information form was sent via e-mail to the instructors whose resumes could not be reached. However, no response was received from the instructors who were sent an e-mail. Therefore, the instructors whose CVs are not included in the web pages and who did not respond to the information form sent by e-mail were not included in the study. This research is limited in time to 2021.

\subsection{Universe and Sample}

There are a total of 41 universities in Turkey, 24 of which are private and 17 state, which include the civil aviation cabin services program and accept students according to the OSYM's 2021 guide. The universe of the study consists of lecturers 
working in the civil aviation cabin services program of 41 universities in Turkey. 3 foundation universities were not included in the study because their web pages could not be reached. For this reason, the sample of the study consists of lecturers working in 38 universities.

Table 1: Number of Private and State Universities

\begin{tabular}{lccc}
\hline & Total Number of Universities & University with Data & Percentage (\%) \\
\hline Private & 24 & 21 & 87,50 \\
\hline State & 17 & 17 & 100 \\
\hline Total & 41 & 38 & 92,60 \\
\hline
\end{tabular}

In this study, data were obtained from a total of 41 universities, including 24 private and 17 state universities. In other words, $92.60 \%$ of the universities that accept students to the civil aviation cabin services program in Turkey have been reached.

Table 2: Number of Teaching Staff in Private and State Universities

\begin{tabular}{lcc}
\hline & Academic Staff & Percentage (\%) \\
\hline Private & 75 & 59 \\
\hline State & 52 & 41 \\
\hline Total & 127 & 100 \\
\hline
\end{tabular}

According to Table 2, while the number of teaching staff working in private universities is 75 , the number of teaching staff working in state universities is 52.

Table 3: Graduation Status of Faculty Members at Private Universities

\begin{tabular}{lcc}
\hline Graduation Status & Academic Staff & Percentage (\%) \\
\hline Bachelor Degree & 34 & 45,30 \\
\hline Master Degree & 32 & 42,70 \\
\hline Doctorate & 9 & 12 \\
\hline Total & 75 & 100 \\
\hline
\end{tabular}

Looking at Table 3, it is seen that $45.30 \%$ of the teaching staff working at private universities are undergraduate graduates, $42.70 \%$ graduate and $12 \%$ doctoral graduates.

Table 4: Graduation Status of Faculty Members at State Universities

\begin{tabular}{lcc}
\hline Graduation Status & Academic Staff & Percentage (\%) \\
\hline Bachelor Degree & 20 & 38,50 \\
\hline Master Degree & 26 & 50 \\
\hline Doctorate & 6 & 11,50 \\
\hline Total & 52 & 100 \\
\hline
\end{tabular}

It is seen in Table 4 that $38.50 \%$ of the teachers working in higher state universities graduated, $50 \%$ of them graduated and $11.50 \%$ of them graduated.

Table 5: Aviation Graduation Status of Faculty Members at Private Universities

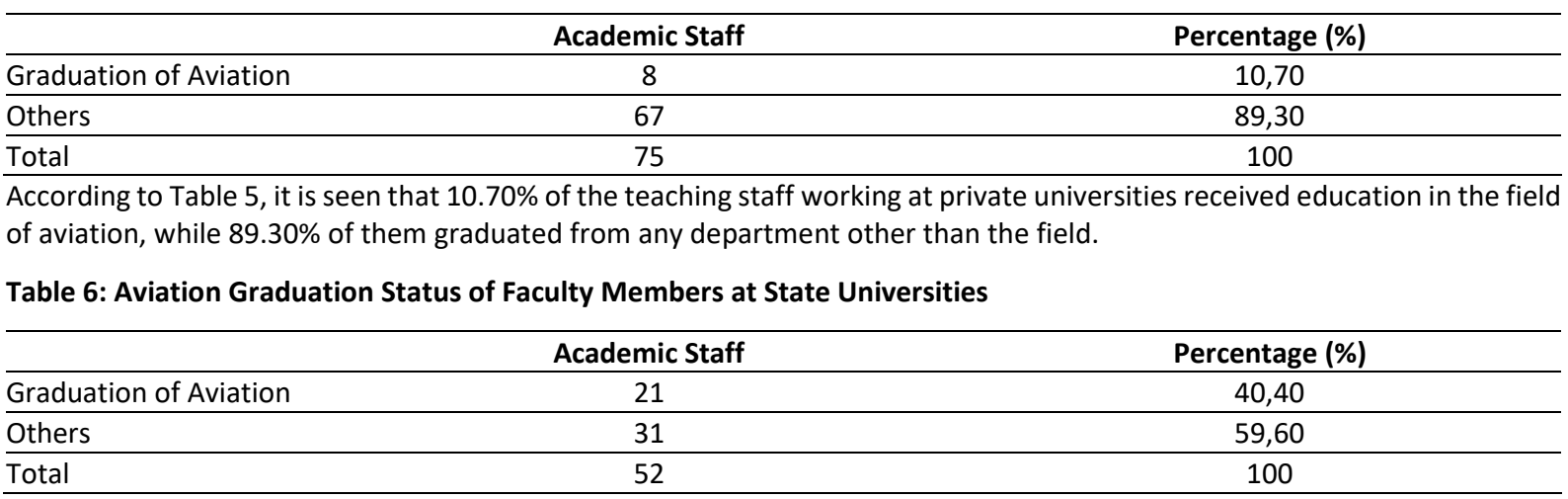


Looking at Table 6 , it is seen that $40.40 \%$ of the lecturers working at state universities have received education in the field of aviation, while $59.60 \%$ have graduated from any department other than the field.

Table 7: Distribution of Academic Staff at Private Universities by Titles

\begin{tabular}{lcc}
\hline & Academic Staff & Percentage (\%) \\
\hline Lecturer & 66 & 88 \\
\hline Lecturer with PhD & 2 & 2,70 \\
\hline Assistant Professors & 7 & 9,30 \\
\hline Total & 75 & 100 \\
\hline
\end{tabular}

Looking at Table $7,88 \%$ of the lecturers at foundation universities are lecturers and $2.70 \%$ are lecturers with phd. and $9.30 \%$ are assistant professors.

Table 8: Distribution of Academic Staff at State Universities by Titles

\begin{tabular}{lcc}
\hline & Academic Staff & Percentage (\%) \\
\hline Lecturer & 46 & 88,50 \\
\hline Lecturer with Phd. & 4 & 7,70 \\
\hline Assistant Professors & 2 & 3,80 \\
\hline Total & 52 & 100 \\
\hline
\end{tabular}

Looking at Table 8 , it is seen that $88.50 \%$ of the lecturers at state universities are lecturers, $7.70 \%$ are lecturers with phd and $3.80 \%$ are assistant professors.

Table 9: Airline Experience of Faculty Members at Private Universities

\begin{tabular}{lcc}
\hline Airline Expriences & Academic Staff & Percentage (\%) \\
\hline Available & 47 & 62,70 \\
\hline None & 28 & 37,30 \\
\hline Total & 75 & 100 \\
\hline
\end{tabular}

Looking at Table 9, it is seen that $62.70 \%$ of the instructors at private universities have aviation experience, while $37.30 \%$ have no aviation experience.

Table 10: Airline Experience of Faculty Members at State Universities

\begin{tabular}{lcc}
\hline Airline Expriences & Academic Staff & Percentage (\%) \\
\hline Available & 8 & 15,40 \\
\hline None & 44 & 84,60 \\
\hline Total & 52 & 100 \\
\hline
\end{tabular}

Looking at Table 10 , it is seen that $15.40 \%$ of the lecturers at state universities have aviation experience, while $84.60 \%$ have no aviation experience.

\section{CONCLUSION AND RECOMMENDATIONS}

It is sufficient to have a bachelor's degree in order to train in the civil aviation cabin services program. Despite this, it is seen that $42.70 \%$ of the teaching staff working at private universities and $50 \%$ of the teaching staff at state universities are graduates. This shows that almost half of the instructors want to advance academically.

It is seen that $10.70 \%$ of the teaching staff working at private universities and $40.40 \%$ of the teaching staff at state universities graduated from the aviation department. The fact that aviation schools do not have a very old history and that the number of graduates from this department until recently was very low, has made it necessary to employ faculty members who graduated from different departments in this program. Although academic staff graduated from different departments can add different perspectives to this field, it can be expected that the rate of academic staff graduating from aviation departments, especially in foundation universities, will be higher. E.g; Faculty members who graduated from different departments can contribute to themselves academically by studying aviation management in open education faculties. 
While the rate of academic staff working as a lecturer is $88 \%$ in private universities, this rate is $88.50 \%$ in state universities. Considering that the academic staff in vocational schools are generally composed of lecturers, it is quite normal for this rate to be high.

It is seen that $62.70 \%$ of the teaching staff at private universities and $15.40 \%$ of the teaching staff at state universities have aviation experience. Kiracl, Bayrak, and Kurt (2013) conducted a study on the lecturers of the civil air transport management departments of 25 universities in Turkey. According to the findings of the study, it was seen that $36.84 \%$ of the lecturers of the civil air transportation management department had industry experience. Since the lecturers who are the subject of our study work in vocational schools, it was thought that those with aviation experience would be high, but the rate of experienced lecturers in state universities was quite low.

Flight attendant training requires practice, this training is not given only on course grades, but also professional experience must be shared with students. Tezeken (2015) conducted a master's thesis in order to reveal the views of the trainers and administrators working in airline companies about the civil aviation cabin services program. The universe of the study consists of 6 airline companies operating in Istanbul. The opinions of the company trainers and administrators interviewed in the study are as follows:

- 'We have cabin attendants who graduated from this department. They say they didn't learn much during the two years in the civil aviation cabin services program."

- "The civil aviation cabin services program is useful in promoting the cabin crew profession, but the trainings provided do not meet the needs of airline companies yet. Flight attendant experience should also be sought from faculty members at universities."

- "Courses such as emergency rules, crew resource management and aviation safety should be taught by instructors with professional experience. It is not enough to teach through the documents obtained from airline companies. Instructors who have been trained in the sector and even have been instructors should be assigned to universities."

- I I am against transferring cabin crew training to students by reading from books. Trainings should be given by people who know this profession, experiences and experiences should be transferred to students."

In the next period, it is recommended that state universities pay more attention to professional experience when recruiting instructors for the civil aviation cabin services program. The experience requirement, which is usually at least 2 years, can be increased to 5 years. Because experience in aviation is very important.

In the aviation sector, there should always be cooperation between the university and the sector. It may be recommended to provide training to instructors who do not have aviation experience by sector representatives or trainers, and to follow the developments in the sector on time and on site. On the other hand, the civil aviation cabin services program is not offered to many universities; It would be more appropriate to open it to cities where the sector is concentrated or where airline companies operate, or to cities or districts close to these cities.

In the aviation industry, the legislation changes very frequently, the rules and procedures are constantly revised. Therefore, the professional knowledge of the instructors should also be up-to-date. Seminars can be organized by airline companies and instructors can be invited to these seminars.

Finally, in today's conditions where internet usage is so intense, it is seen that some private universities do not have resumes of academic staff on their web pages, only their names and contact addresses. Giving the necessary importance to this issue by the relevant units of the universities will be beneficial both in terms of professionalism and in terms of carrying out studies with more participants.

\section{REFERENCES}

Aktunç, i.., (2013). Yolcu memnuniyeti. Cabin Interphone Dergisi, 1, 18-19.

Baltaş, A., (2009). Kabin memurunun kişiliği. TASSA Hava Yolları Kabin Memurları Derneği Dergisi, 9, 22-23.

Bingöl Üniversitesi Sosyal Meslek Yüksekokulu. (2021). http://sbmyo.bingol.edu.tr/programlar_/sivil-havacilik-ve-kabin-hizmetleri-programi/ [Date Accessed: September 9, 2021].

Bolat, Y., (2011). Gazi Üniversitesi Meslek Yüksekokulu Öğrencilerinin Sosyal Değerlere Bakışları. Yüksek Lisans Tezi, Gazi Üniversitesi Eğitim Bilimleri Enstitüsü Eğitim Bilimleri Ana Bilim Dalı, Eğitim Programları ve Öğretim Bilim Dalı, Ankara.

Çolak, N., (2013). Havacılık sektöründe değişen beklentilerin eğitim ile karşılanması ve bu süreçte kabin memuru rolü. Türk Hava Yolları Turkish Aviation Academy Dergisi, 6, 38-39.

Dervişoğlu, F. M., (2017). Nuri Demirağ Türkiye'nin Havacılık Efsanesi. Ötüken Yayınevi, İstanbul, ISBN: 975-437-617-4 
DHMi, 2020 Havayolu Sektör Raporu (2021).

https://www.dhmi.gov.tr/Lists/HavaYoluSektorRaporlari/Attachments/14/2020_Havayolu_Sektor_raporu.pdf [Date Accessed:September $15,2021]$.

Eskişehir Teknik Üniversitesi Havaclık ve Uzay Bilimleri Fakültesi. (2021). http://ecas.anadolu.edu.tr/ [Date Accessed: September 18, 2021].

Günal, S. ve Koçak, N. (2003). Meslek Yüksekokullu Öğrencilerinde Sınavsız Geçiş Sonrası Ortaya Çıkan Yapısal Değişimin illk Değerlendirmesi. Ege Meslek Yüksekokulu II. Ulusal Meslek Yüksekokulları Sempozyumu, 15-17 Ekim 2003, İzmir.

Kapadokya Meslek Yüksekokulu. (2021). https://kapadokya.edu.tr/akademik/kapadokya-meslek-yuksekokulu/havacilik-programlari [Date Accessed: September 5, 2021].

Kızılcan, S., Demiral, G., (2021). Kabin ekibinin mesleki tükenmişlik düzeyinin incelenmesi: bir özel havayolu şirketi örneği. Havacılık ve Uzay Çalışmaları Dergisi, 2, 17-46.

Kiracı, K., Bayrak, Ü., Kurt, Y., (2013). Türkiye'deki Sivil Hava Ulaştırma Iş̧letmeciliği Bölümü Öğretim Eleman ve Yardımcılarının Akademik Özgeçmişlerinin Nicel Görünümü. Uhat-2013, II. Ulusal Havacılık Teknolojisi ve Uygulamaları Kongresi, 29-30 Kasım 2013 Gaziemir/izMiR, 505-518.

Ösym Yükseköğretim Programları ve Kontenjanları Kılavuzu (2021).

https://dokuman.osym.gov.tr/pdfdokuman/2021/YKS/kntkilavuz05082021.pdf\#page=467 [Date Accessed: September 1, 2021].

Shgm Kabin Memuru. (2021). http://web.shgm.gov.tr/tr/havacilik-personeli/2138-kabin-memuru [Date Accessed: October 3, 2021].

SHGM Tarihçe. (2021). http://web.shgm.gov.tr/tr/kurumsal/1-tarihce [Date Accessed: October 5, 2021].

Tezeken, Ö., (2015). Sivil Havacılık Kabin Hizmetleri Eğitim Programı ile ilgili Hava Yolu İşletmelerinde Görevli Eğitimcilerin ve İdarecilerin Görüşleri Üzerine Nitel Bir Araştırma. Yüksek Lisans Tezi, Yeditepe Üniversitesi Eğitim Bilimleri Enstitüsü, Eğitim Yönetimi ve Denetimi Yüksek Lisans Programı, İstanbul.

Turan, S., (2002). Teknolojinin okul yönetiminde etkin kullanımında eğitim yöneticisinin rolü. Kuram ve Uygulamada Eğitim Yönetimi, 30, 27188.

Türk Hava Yolları, Hikâyemiz, (2021). https://www.turkishairlines.com/tr-int/basin-odasi/hakkimizda/hikayemiz/ [Date Accessed: September 4, 2021].

Uşak Üniversitesi Sivil Havacılık MMO. (2021). https://sh.usak.edu.tr/birim/560 tarihçe [Date Accessed: October 6, 2021]. 